\title{
Value Migration, Status and Functions: A New Classification in Shiite Political Culture
}

\author{
Zahed Ghaffari Hashjin ${ }^{1}$, Mohammad Aghaei ${ }^{1} \&$ Mohammadreza Fathimehr $^{2}$ \\ ${ }^{1}$ Humanities Faculty, Shahed University, Tehran, Iran \\ ${ }^{2}$ Theology Faculty, Imam Sadiq University, Tehran, Iran \\ Correspondence: Mohammad Aghaei, Humanities Faculty, Shahed University, Tehran, Iran. Tel: \\ 98-91-2737-5208. E-mail: aghaei_1387@yahoo.com
}

Received: March 4, 2016 Accepted: March 21, 2016 Online Published: May 29, 2016

doi:10.5539/jpl.v9n4p53 URL: http://dx.doi.org/10.5539/jpl.v9n4p53

\begin{abstract}
Human civilization has always generated by great migrations and exactly that is why research on migration one of the basic components of political science neglected unfortunately. In Islamic culture, especially in Shiite political culture, migration is valuable. The value of migration in the Shiite political culture is due to migration of the Prophet of Islam. Therefore, the main question is what is the roles and functions of migration in the Shiite political culture? To answer this question, were referred to first-hand and old sources of Shiite Islam. Providing a new classification, we concluded that it has important status and has five functions in Islam, including political, security, educational, social, and Preaching functions.
\end{abstract}

Keywords: value migration, Shiite political culture, a new classification

\section{Introduction}

After the migration of the prophet Mohammad (peace be upon him) the concept of migration among Muslims earned a significant position and in the political culture of the Shiites it earned a divine and spiritual place. To have a correct understanding of this ancient pattern there is no choice but to refer to the main Shiite Islamic jurisprudential theologian, and mystical sources and since the first-hand Shiite sources go back to the first centuries of Islam and are mostly written in Arabic it is necessary to study and delve into the ancient Islamic sources to gain a correct understanding of the concept of migration and study the ancients texts in order to understand the intention of the Islamic elites of this concept. Researchers in this essay are making an attempt to gain and present a deep understanding of this concept in the political culture of Shiism by referring to the four books of Shia and the first-hand books on the history of Islam and the ancient Islamic texts and by applying the documentary analysis method. The concept of migration in the glorious Quran as the main source for understanding the religious concepts among the Shiites has inserted in various ways in several parts of this divine book. In an enumeration which the researchers of the present study have done this concept have been inserted for thirty one times in several situations and following several Quranic verses. (cf. the glorious Quran, Surah al-baqarah, $218^{\text {th }}$ verse, Surah Al-Imran, $195^{\text {th }}$ verse, Surah Al-Nisa, $89^{\text {th }}$ and $97^{\text {th }}$ and $100^{\text {th }}$ verses, Surah Al-Anfal, 72th and $74^{\text {th }}$ and $75^{\text {th }}$ verses, Surah Al-Touba, $20^{\text {th }}$ and $100^{\text {th }}$ and 117 th verses, Surah Al-Nahl, 41th and $110^{\text {th }}$ verses, Surah Al-Hajj, $58^{\text {th }}$ verse, Surah Al-Noor, 22th verse, Surah Al-Ankabut, $26^{\text {th }}$ verse, Surah Al-Ahzab, $6^{\text {th }}$ verse and so forth.) When we refer to the interpretations of these verses and the Islamic narrations which are being inserted following each verse from The Infallibles we get that the concept of migration in the thoughts of Shiism has five fundamental functions which we cover each one of them independently in the sections of the essay.

It is worth noting that in the present subject of discussion in the academic societies and the scientific journals to the extent of the investigation which is done by the authors of this essay no independent work has been presented up to now and no scientific essay has been written and the findings of the present study are being presented for the first time.

\section{Theoretical Framework: Political Culture of Shiism}

Up to now multiple definitions of the concept of culture have been presented. For instance, in Burnett Taylor's opinions culture is a complicated and convoluted series of knowledge, belief, arts, ethics, law, customs, and the 
whole capabilities and habits which people deal with them. (Burnett Tylor, 2010, p.56) Gabriel Almond holds that as the beliefs and attitudes of individuals impacts their deeds and behavior political culture influences the deeds and behaviors of citizens and the leaders of a society and their interrelationships as well. He describes the political culture as a specific distribution of political values, sentiments, information, and skills. (Almond \&Verba, 1990, p.95) In this area Tennessee holds that the mental and intellectual atmosphere in which politics has developed in it and has been interpreted and judged is the same political culture. (Tennessee, 2000, p.149) ; while Verba views the political culture as a system of experience able creeds and institutions and values which are the cornerstone and foundation of any political activity. (Verba, 1988, p.213) Noting this definitions the concept of political culture becomes more and more obvious and at present we can present an independent definition of the political culture of Shiism: The political culture of Shiism is a coherent and sophisticated series of a belief system, a value system, symbols, and the political networks which have been achieved from first-hand belief sources and the ancient Shiite theologian sources which is the basis for the political action, orientation, and behaviors of the Shiites against the internal and international political and governmental system. It should be noted that the political culture of Shiism can be studied through two approaches: religious approach and the non-religious approach. The theoretical framework of the present study is the political culture of Shiism with a religious inclination.

The political culture of Shiism has a belief and value system which embraces some factors that one of the most significant of them is the concept of migration.

\section{Migration in the Political Culture of Shiism}

\subsection{Generalities}

Migration (hijra) semantically has a general sense and it consists in leaving one's own homeland and/or transfer from a place to another place to earn a living but this concept in the terminology of political sciences of Islam means leaving one's own homeland while one is surrounded by infidels and entering an Islamic atmosphere. (Saliba \& Sanayi Darreh Bidi, 1987, p. 672) Migration idiomatically means leaving one's home land and going toward God and its prophet but what does going toward God and its prophet mean? The main condition for migration toward God and its prophet is having a divine intention and if this condition doesn't exist not any kind of migration may occur in the political culture of Shiism. (Ibn-Arabi, sine datum, $1^{\text {st }}$ vol. p.209; Majlesi, 1406 Anno Hejira, $1^{\text {st }}$ vol.p.340;Naraghi, sine datum, $3^{\text {rd }}$ vol. p.112; Mousavi al-Khomeini, 2009. P.121. In fact in the political culture of Shiism any migration which bears a religious purpose is perceived as a migration toward God and its prophet either for seeking knowledge, performing Hadj rites, or to arrive at the territory of the believers. According to this definition a migrant is one who avoids anything which is prohibited by God and/or gives up moving toward falsehood to achieve truth. (Toreyhi, 1996, $3^{\text {rd }}$ vol.pp.515-516.)

As such a definition is presented of migration it is possible to mention some cases as its manifestation even before the rise of Islam. According to this definition Sheikh Eshragh as one of the leading Shiite philosophers mentions Freydun who is one of the mythical kings of the ancient Iran as one of the individuals who migrates which means migration in its idiomatic sense in the political culture of Shiism. (Sohrevardi, s1996, $3^{\text {rd }}$ vol.pp.186-188.)

\subsection{Functions of Migration}

According to the discussions which have come above after studying the main sources of Shiism we perceive that the concept of migration in the political culture of Shiism has various functions and it is being mentioned under various discussions. But if we want to put various Islamic narrations under a kind of classification we can categorize the function $\mathrm{s}$ of migration under five cases: political migration, security migration, educational migration, social migration, and preaching migration that figure1 shows these. 


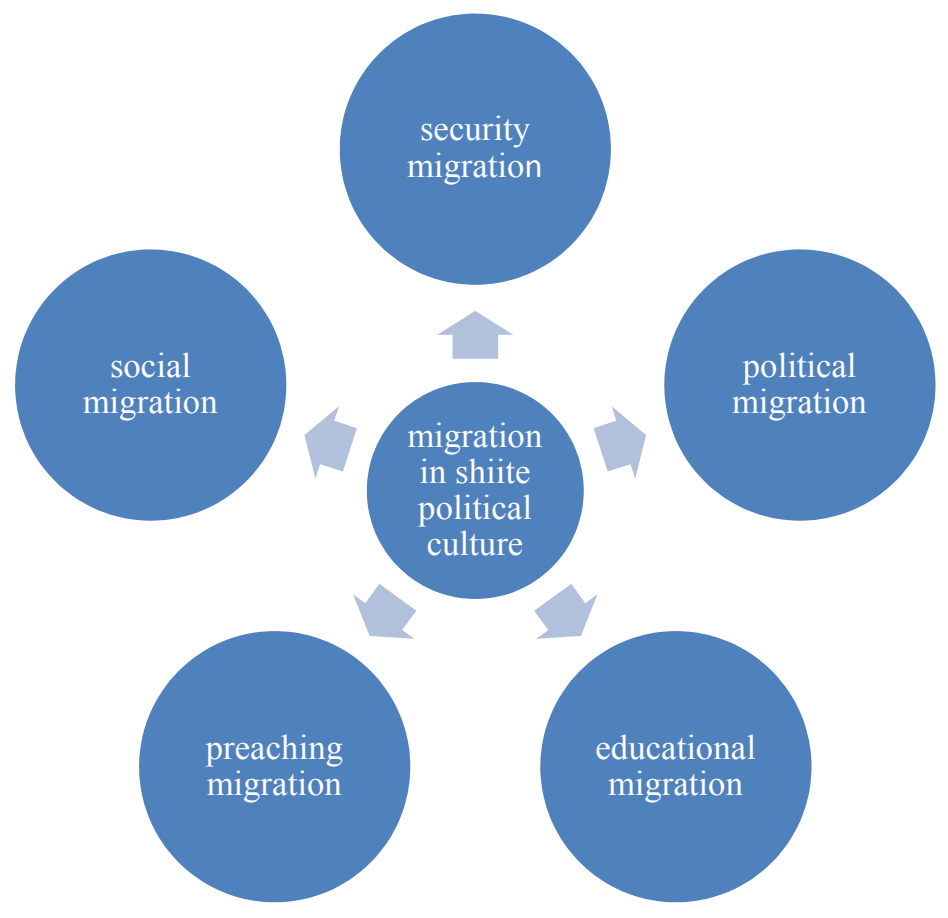

Figure 1. Migration in Shiite political culture

Concerning each kind lots of examples of valid Islamic narrations exist in the political culture of Shiism and several explanations and interpretations from the highest-ranked Shiite canonists on this issue. It is note mentioning that by considering the inexistence of any scientific and academic research in this area the above classification and the presented categorization in this study is totally inventive and is from among the heuristic discussions of the authors of the essay.

\subsubsection{Political}

From among the most significant functions of migration in the political culture of Shiism is its political function. In the ancient Shiism texts has been inserted that while a tyrant government rules over a society it is on a Shiite Muslim to revolt against the tyrant government and the corrupt society and migrate to protest against the illegitimate ruler. The first one who did such a thing was the arch prophet Abraham who migrated to protest against his concurrent corrupt ruling and society. (Kashani, 2000, p.474.) Another political function of migration in the political culture of Shiism was to establish a divine government and observing the religious instructions. (Ghazzali, sine datum, $3^{\text {rd }}$ vol. p.492.) It means that if Muslims settle in any place which the requirements of establishing a divine government is impossible to establish an Islamic government it is necessary to migrate from that territory and move to another territory in which the possibility of establishing a divine government is possible.

\subsubsection{Security}

Another function of migration in the political culture of Shiism is the concept of security migration. Essentially the domain of security and the security studies embrace the period before armed conflict and/or the war. Due to this, the security migration takes that aspect of migration into account which refers to the peace time and before the armed conflict. In the narrations which are remained from the Infallible imams in Islam following the interpretation of the verse $218^{\text {th }}$ of the Surah Al-Baqarah in the glorious Quran a practical example of the security migration is being mentioned. IN the book Al-Dor Al-Mansur (Sioti, 1404 A.H.) a narration is inserted that says the prophet Mohammad (peace be upon him) before the outbreak of the war of Badr called one of his followers named Abdullah Ibn Jahish and granted him a letter and dispatched eight of his subjects after him and ordered him to open the letter and read it as arrives at such and such place. Abdullah went after that eight subjects and arrived at the arranged place and they opened the letter and encountered a decree to carry out a security migration by the prophet Mohammad. The prophet (peace be upon him) ordered them to go to the territory called Nakhlah which is place between Meccah and the city of Taif in Saudi Arabia and keep an eye on the Quraysh tribe and report it to Mohammad. (Tabatabaee, $1417 \mathrm{AH}, 2^{\text {nd }}$ vol.p.189) This narration is one of the key reasons 
for proving the existence of a security migration in the political culture of Shiism.

\subsubsection{Educational}

The third function of migration in the political culture of Shiism is the educational aspect of migration. Education in the political culture of Shiism has a specific meaning and means detaching egoism from oneself and approaching the position of self-sacrifice and prioritizing others as much as possible. Due to this in the genuine Shiite etxts the believers in Islam are advised to migrate to set aside egoism and avoiding any abominable character trait. (Sajadi, 1994, ${ }^{\text {rd }}$ vol. p.2175.) The eminent point in this kind of migration is that it has two internal and external kinds. In the first kind there is no need to dislocation and moving in and there is no materialistic shape but this kind of migration may be an innate migration which means a spiritual migration for changing into an ideal human. Of course the educational migration may be of the external type that is it involves dislocation and moving in. For instance, it may be necessary to migrate for God's sake and to seek knowledge and finally to become moral-oriented. (Sajadi, 1994, $3^{\text {rd }}$ vol.p.2175.) An individual who has adorned him/herself with moral virtues and is free from egoism is efficient for governing in a political system and is able to take the responsibility of leading a society since the characteristic of justice is being manifested in him/her.

\subsubsection{Social}

The fourth function of migration in the political culture of Shiism is the social aspect. The nicety which exists here is that traveling and paying a visit to the slightly places in the political culture of Shiism is mentioned as migration on condition that one has a pure intention and takes the satisfaction of God into consideration as agoal. (Sajadi, 1994, $3^{\text {rd }}$ vol.p.1507.) Due to this it is necessary for the rulers and the policy makers to pay serious attention to the issue of halal tourism and its financial and intellectual benefits and revenues and schedule for the facilitation of tourism.

The main social institution in the political culture of Shiism is the family. Paying attention to the family and strive for the sake of it is so much important that according to an Islamic narration (hadith) by Mohammad doing good to the parents and trying to make them happy and making them laugh is by itself considered as a kind of migration toward God and its prophet. (Ghazzali, 2007, $2^{\text {nd }}$ vol. p.470) and has tremendous intellectual value. In this case migration doesn't need to dislocation and going through a distance as well but the innate concept of migration is taken into consideration.

\subsubsection{Preaching}

The fifth function of migration in the political culture of Shiism is the preaching aspects of migration. Preach semantically means taking and idiomatically means doing something by which the voice of the genuine Islam reaches the people all over the world. Due to this in the authentic Shiite texts migration has been repeatedly recommended to yield benefits for humans and illuminating the genuine Islamic wisdoms. (Sajadi, 1994, $3^{\text {rd }}$ vol. p.2175) Preaching migration means the believers should take any opportunity to feel reverence for the rights of other humans and behave the whole humans with good manners and an open face that in case they do so the followers of other religions will be influenced by their good manners and will incline toward Islam and finally will be interested in the Islamic government and will approach it which is the propagator of such a culture more than ever. The element of benevolence and affection in the preaching migration is of high priority.

\section{Conclusion}

To find the correct understanding of an Islamic culture, it is needed that value and belief components of that culture to be studied comprehensively so get a clear image of it, by referring to old and first-hand texts of it. Migration is an important component of value and belief system of Shiite political culture that unfortunately has not been studied and considered seriously. In this study, we referred to main and old Islamic texts to get a clear and precise image, and we achieved to new classification of its status and functions in Shiite political culture by analyzing theoretical and practical examples. It is first achievement so that independent work has not been written about it so far. The findings suggest that migration has five functions in Shiite political culture including, political migration, security migration, social migration, educational migration, and preaching migration. What is important here is that in the Shiite political culture, migration is not merely an extroverted concept, but its mystical and introspective aspect has great importance that it will be discussed in another separate study.

\section{References}

Almond, G. A., \& Verba, S. (1990). The Civil Culture: Political Attitudes and Democracy in Five Nations. Boston: Little Brown.

Burnett Tylor, E. (2010). Primitive Culture. Cambridge: Cambridge University Press. 
Ghazzali, A. H. M. (sine die.). Ehya-e-olum-e-Din. Beirut: Dar-Al-kitab Al-Arabi.

Ghazzali, A. H. M., \& Kharazmi, M. (2007). Translation of Ehya-e-olum-e-Din by Houssein Khadiv jam. Tehran: Elma-va-farhangi Publication.

Ibn Arabi, Mohi-ud-Din. (sine die.). Futuhat Al-Makkiyah. Beirut: Dar-al-sadr Publication.

Ibn Babevayh, M. I. A. (1988). Man La yahdaruhu al-faqih. Translated by Ghaffari Aliakbar;Ghaffari, Mohammad javad; Sadr Balaghi. Tehran: Saduq Publication.

Kashani, Kamal al-Din Abdol razzaq. (2001). Collection of dissertations and writings by Kashani. $2^{\text {nd }}$ publication. Tehran: Miras-e-maktoob Publications.

Kulayni, Muhammad ibn Ya'qub. (1990). Osul-al-kafi. Translated by Seyyed javad Mostafavi. Tehran: Elmieh Eslamieh Bookstore.

Majlesi, M. B. (1406 AH.). Malaz Al akhbar fi Fahm Tahzib Alakhbar. Qom: Ayatollah Marashi Najafi Library.

Mousavi Al-khomeini, S. R. (2009). Translation and interpretation of the Dawn worship. Translated by Seyyed Ahmad Fahri. Tehran: Institute for the compilation and publication of the works of Imam Khomeini. (peace be upon him).

Naraghi, M. M. (sine die.). Jami Al-Saadat. Beirut: The Scientific Institute for the Press.

Sajadi, S. J. (1994). Islamic Culture Dictionary (3rd ed.). Tehran: Tehran University Publication.

Saliba, J., \& Sanayi Darreh Bidi, M. (1987). Dictionary of Philosophy. Tehran: Hekmat Publication.

Sioti, J.-A.-D. (1983). Al-Dur Al-Manthur Fi Tafsir Al-Maásur. Qom: Ayatollah Marashi Najafi Library.

Sohrevardi, S.-A. (n.d.). A Collection of works by Sheikh Eshragh. Tehran: Institute for the Cultural Studies and Researches.

Tabataba'I, S. M. H. (1996). Al-Mizan Fi Tafsir al-Quran. Qom: Office for the Islamic Publication.

Tennessee, S. D. (2000). Foundations of Politics. Translated by Malek Mohammadi, Hamidreza. Tehran: Dadgostar Publication.

The Glorious Quran.

Toreyhi, Fakhr-al-Din. (1996). Majma Al-bahrain (3rd ed.). Tehran: Mortazavi Bookstore.

Verba, S. (1988). Compative Political Culture. American Political Science Review, 82(4).

\section{Copyrights}

Copyright for this article is retained by the author(s), with first publication rights granted to the journal.

This is an open-access article distributed under the terms and conditions of the Creative Commons Attribution license (http://creativecommons.org/licenses/by/3.0/). 